\title{
Buy, Borrow, or Steal? Film Access for Film Studies Students
}

\section{Wendy Rodgers}

\begin{abstract}
Libraries offer a mix of options to serve the film studies curriculum: streaming video, DVDs on Reserve, and streaming DVDs through online classrooms. Some professors screen films and lend DVDs to students. But how do students obtain the films required for their courses? How would they prefer to do so? These are among the questions explored using data obtained by surveying students at one Canadian university as well as faculty and librarians at ten Canadian universities that offer film studies programs. The study finds that more students are engaging in digital piracy than using the Library Reserve desk and that faculty and librarians must contend with formats, licenses, and copyright to provide effective, legal access. The paper recommends that libraries increase streaming options, collect DVDs for preservation, digitize DVDs when legally possible, screen films in class, investigate social screening spaces, and lobby industry and government for changes to law and practice.
\end{abstract}

\section{Introduction}

Film studies students can obtain films required for their courses in many ways. They may view films with a class; borrow DVDs from the library, friends, or the professor; view streaming video through the library website, if titles are available; rent or buy films on DVD or online; or stream or download films online for free. Collections librarians may wonder whether the service traditionally provided by academic libraries - placing one or two DVDs on Reserve for short-term loan-is meeting the needs of students, especially given the range of access options now available. What is the best way to spend a limited film collection budget so that it has the greatest impact, meeting the needs of students and the curriculum as well as the long-term preservation goals of a research library?

Today's students are accustomed to being online all the time, and they turn to the Internet for access to information and entertainment. ${ }^{1}$ Copyrighted music, movies, television, and software can be acquired illegally online for free, and students are taking advantage of this access. ${ }^{2}$ Both the popular and academic literatures have been saturated with reports about the online sharing of copyrighted works, or "digital piracy," in the twenty-first century. ${ }^{3}$ But the literature on digital piracy has focused on piracy

*Wendy Rodgers is Humanities Research Liaison Librarian in the Queen Elizabeth II Library at Memorial University of Newfoundland; e-mail: wrodgers@mun.ca. The author would like to thank Dr. Dianne Keeping, Sharon Norton, and Dr. Patricia Dold for testing the surveys. (C2018 Wendy Rodgers, AttributionNonCommercial (http://creativecommons.org/licenses/by-nc/4.0/) CC BY-NC. 
for entertainment purposes. There has been very little study on how students behave when they are required to obtain media for a university course-when viewing films is essential for achieving success. Further, we do not know what challenges faculty and librarians face when attempting to facilitate students' access to films to meet their curriculum requirements.

This topic is important for academic libraries to consider. When used in courses, films are university texts that students must obtain. A professor would rarely assign an out-of-print book as a primary course text and expect a class to share one library copy, yet out-of-print films are often the norm in film studies, and the library is expected to provide access to them. Often, films are only available legally on DVD (if they are available legally at all). Streaming video may be a preferred format, but services may not provide enough of the required films to make them worthwhile, particularly in the case of feature films. If libraries buy DVDs for film studies courses and they go unused, do DVDs represent good value? The issue of copyright underpins these considerations; libraries must comply with copyright, and students should be able to secure convenient access to required films without having to act illegally.

Using data obtained by surveying students at one Canadian university, and faculty and librarians at ten Canadian universities, this paper explores what kind of access to required films is being provided by Canadian universities that offer Minor programs in film studies. It asks whether and how students obtain films, how students would prefer to obtain them, and what role libraries and professors can play in providing better access on campuses where film budgets are likely to be very limited. It is expected that few students are accessing films through the Library's Reserve Desk, that more students are engaging in digital piracy than using Reserve, and that faculty and librarians are encountering challenges in trying to provide effective and legal access to films.

\section{Literature Review}

This research examines the experiences and needs of film studies students, faculty, and librarians, which have not been addressed directly in the literature. A wide range of literature was consulted, and this review includes several relevant areas: academic library film collection formats; faculty experiences and attitudes toward teaching with film; digital piracy; and how students obtain media.

DVDs have been the primary film format in libraries for many years. Writing in 2010 about how companies like Netflix and Redbox were increasing their streaming offerings and reducing DVD services, Benjamin Malczewski wrote that "the road appears paved for libraries to become the primary lender of DVDs to U.S. consumers. But are DVDs going to remain relevant much longer?"' Indeed, the recent literature on academic library film collections shows that libraries are also examining the shift from DVD to streaming, discovering many significant issues along the way.

The ease and convenience of streaming video is appealing to both libraries and their users. Gary Handman writes that streaming video can meet user demand for easy $24 / 7$ access, replace deteriorating collections in older formats, provide multiple copies, liberate library space given to viewing facilities, and facilitate incorporation into courseware. ${ }^{5}$ Yet Rachel King asserts that "streaming video... threatens the ability of libraries to provide films to patrons." ${ }^{\prime 6}$ King describes the unique value of a library, a collection based on the stated or perceived needs of users and which preserves obscure and out-of-print material, noting that such features "cannot be guaranteed by any forprofit service that seeks primarily to serve a consumer market." ${ }^{\prime 7}$ Even if a streaming video package offers institutional access and relevant films, titles may disappear from the package at any time, "making it difficult for faculty to reliably build syllabi and lesson plans around them." ${ }^{8}$ 
King's approach to films in the academic library is to build hybrid collections. She cites an instance at UCLA of a practice that is becoming more common at academic institutions: DVDs are copied and streamed only to students enrolled in a specific class. King describes DVDs as "protean digital content" that, if legally converted to a streamed format, will give libraries "the flexibility that Hollywood appears to be trying to take away." ${ }^{\prime 9}$ John Vallier reports on a similar project at the University of Washington that resulted in "a fourfold increase [in use] over our traditional in-house reserve service" of short-term DVD or VHS loans. ${ }^{10}$ Film studies professor Haili Kong also streams DVDs via courseware. Among the drawbacks he notes are the need for substantial technical support, and that "the film's special audiovisual effects... are often less evident on the small personal computers typically used for Blackboard film 'streaming.'"11

Streaming video raises greater legal issues than other formats. Bryan James McGeary notes that legal barriers will prevent libraries from sharing their streaming resources with each other, and he calls on libraries to collaborate to ensure that streaming and sharing can coexist. ${ }^{12}$ In spite of the legalities of public performance rights, Ciara Healy surmised in 2010 that professors were screening Netflix DVDs in class. ${ }^{13}$ Although the DVD service is no longer operating, some professors are likely using their personal subscriptions to stream Netflix for class use. ${ }^{14}$ In light of consumer-licensed collections like Netflix, William Cross examines U.S. copyright law and finds a way forward, concluding that "libraries can engage with consumer-licensed services confidently... [i]f services like Netflix continue to ignore the library market." ${ }^{15}$ Whether intended for the academic or consumer market, streaming services will involve increased legal complexity.

Beyond the intricacies of collection development, faculty attitudes and experiences must be considered when determining the future of film access. Jane Johnson Otto examines the practices of faculty teaching with film in several disciplines at Rutgers University and reports their attitudes toward formats. ${ }^{16}$ Nearly half $(44 \%)$ of faculty prefer web-based video over other formats (Otto notes this number would be higher but for technical issues specific to Rutgers) ${ }^{17}$ Faculty want to incorporate video into courseware but feel limited to what is free online, which is "not what they would choose to show in the classroom."18 One-third think that "it is too hard/takes too long to get the video" (that is, the DVD) from the library collection. ${ }^{19}$ In terms of action, Otto reports that Rutgers plans to provide a streaming server to deliver video to their campuses. ${ }^{20}$

Film studies professors have also addressed film access within their literature. Dina Iordanova has organized training sessions for doctoral students on accessing BitTorrent and cyberlocker sites, but she says it is no longer necessary thanks to YouTube and similar sites. ${ }^{21}$ She is optimistic about the future of online access to film, pointing to video shared on BitTorrent sites that "effectively create archives of personal archives" that are "backed-up, saved, and stored in multiple copies to subvert possible takedowns by copyright watchdogs." 22 She calls on "scholars with access to the filmmakers, their producers and distributors, to consider solicitation for nonremoval [such as from YouTube] as an act of public activism, or to lobby for at least making the films available in commercial distribution at reasonable prices." ${ }^{23}$ She also calls for the "academic organization of material" on YouTube, IMDb, and virtual film festivals. ${ }^{24}$

Iordanova's optimism about BitTorrent archives should be tempered by concerns about copyright and piracy. The literature on digital piracy is vast and appears in many disciplines. It has received some attention within recent library literature, but the focus has been on e-books and journal articles, not films. In 2007, Dean Hendrix found that librarians had a neutral or indifferent attitude toward peer-to-peer (P2P) technologies, although " $66 \%$ believe that P2P facilitates theft of copyrighted works." ${ }^{25}$ In her survey of the literature on the ethics of digital piracy, Kate Gray notes that torrent sites such 
as The Pirate Bay offer all types of media; she suggests that the entertainment industry "mimic this ease in their own methods of delivering content" rather than forcing users to search multiple sites. ${ }^{26}$ She also calls on artists to use direct delivery methods that bypass production companies.

The criminology, economics, and business literature overflow with studies on digital piracy. ${ }^{27}$ Postsecondary students are frequently the subject of such studies, which often conclude by favoring one or more of these solutions: enforcement, education, and legal alternatives. Steven Caldwell Brown describes much of the literature as using "generally weak approaches." ${ }^{28} \mathrm{He}$ notes the one-sided focus on digital piracy as a criminal activity, stating that the word piracy is "inherently subject to bias." ${ }^{29}$ Further, Brown points to researchers who have explored the piracy of different types of media; he introduces the idea of "multiple piracies," suggesting that piracy of different media occur for distinct reasons. ${ }^{30}$ Edwards et al. call for a "repositioning of users as sources of legitimate justifications rather than dysfunctional consumers to be educated or prosecuted." ${ }^{\prime 1}$

The users at the center of this research project are film studies students, whose behaviors and needs have not been addressed within the literature. However, studies about how students obtain media for personal use can be revealing. Chuck Tryon and Max Dawson found that students' viewing choices were influenced by many factors, including their location (such as on or off campus), platform options, convenience, price, and lack of legal alternatives. ${ }^{32}$

Convenience was an influential factor, Tryon and Dawson found. "Students report that they want to do the right thing by content creators [by]... paying for access or watching ads. But when 'the right thing' is something they regard as unnecessarily inconvenient, they find paths of less resistance," such as P2P sources or not watching at all. ${ }^{33}$ Though their survey did not ask about P2P sharing or streaming, 22.3 percent of students at one university commented that they have used such websites on a campus where legal alternatives were unavailable. The authors conclude that piracy "cannot be blamed on the cost of media alone." ${ }^{34}$ In a similar study, Sharon Strover and William Moner report that students "said they actually would prefer an affordable, user-friendly, authorized alternative." ${ }^{35}$ Strover and Moner also found that a significant majority of students who downloaded titles "prefer to keep the file on a hard drive for a long time as opposed to deleting it soon after viewing, suggesting that viewers tend to collect media for repeated access." 36

Both studies examined DVD use. Tryon and Dawson found that "many" students at one university purchased DVDs while in high school, but more than 30 percent no longer do so; some still buy DVDs of titles they have watched online to collect, display, or lend..$^{37}$ Strover and Moner conclude that students who watch DVDs are interested in "a higher-quality image, in particularly valued content, or in content amenable to group viewing (such as a blockbuster movie) on a large screen." ${ }^{38}$

Tryon and Dawson report that students believe "paying full retail price for DVDs or digital downloads is not realistic," considering environmental, economic, and other circumstantial factors. ${ }^{39}$ Strover and Moner conclude that "unauthorized content is a typical component of the digital diet" and that "carving out a particular use of shared files as illegal goes against the grain of a raft of other routine and popular activities within digital life." 40

\section{Research Design and Methodology}

This project was conceived as a descriptive study aimed at observing film access for film studies students. Data was obtained by polling members of film studies programs at several Canadian universities. A total of 84 faculty members, 36 librarians, and 56 
students were invited to complete a questionnaire of 16-20 questions detailing their use and provision of films for university courses.

Sampling was conducted using the 2013 Directory of Canadian Universities in conjunction with Internet searches to identify all Canadian institutions that offer only Minor degrees in film/cinema studies. Ten institutions were identified, with undergraduate populations ranging from 30,000 to 750, listed here from largest to smallest: University of Ottawa, Dalhousie University, Memorial University of Newfoundland, ${ }^{41}$ Mount Royal University, University of New Brunswick, St. Mary's University, Nipissing University, St. Thomas University, University of King's College, and NSCAD University.

Two types of purposive sampling were used. Total population sampling was used for faculty and librarians to capture issues shared by universities that are likely to have smaller film budgets. To ensure that the diversity of the faculty population was represented, program coordinators were sent a list of proposed faculty survey subjects and asked to add names of per-course instructors and other teachers whose names are sometimes omitted from program websites.

In the case of students, homogenous sampling within a single institution was used to avoid access differences among universities. Nevertheless, there will be variance among the student population in terms of the financial and computing resources they can use to obtain films.

Even with fairly high response rates for all groups, the possibility of bias exists: respondents who chose to answer the survey may share commonalities not held by those who declined. And while nonprobability sampling cannot produce a statistically representative sample, it is hoped that an investigation of tightly targeted groups can yield enough responses to allow for transferability, if not generalizability.

Surveys were used to gather a large amount of standardized empirical data efficiently and anonymously. Three surveys were designed. All contained demographic questions, scale questions about behavior and attitudes, and open-ended questions. See Appendix for survey questions.

The Research Ethics Boards at the ten institutions were contacted. Three institutions required full or partial review. The primary ethical concern was that participants were asked whether they had ever engaged in illegal digital piracy. For this reason, anonymity was assured to all participants - the researcher knew which institutions had responded but not which individuals. In addition, student participants were assured that their university would not be named.

Students were polled using a group-administered print questionnaire in three film studies classes in March 2014. Four of the 56 students declined the survey. The response rate was 93 percent $(n=52)$. Two further attempts were made to poll film studies students in successive terms using online surveys targeting both on-campus and distance courses. Response rates from the online surveys were very low, so they were omitted from this analysis.

Faculty were polled using an online questionnaire via the Fluid Surveys platform during August 2014. Six subjects were removed from the sample because they reported that they did not teach film or had moved institutions, leaving 78 . The response rate was 67 percent $(n=52)$.

Librarians were polled using an online questionnaire via the Fluid Surveys platform during November 2014. Six subjects were removed from the sample because they reported that they did not collect films, leaving 30. The technical response rate was 33 percent $(n=10)$, but the practical response rate was 100 percent because responses (via the survey or e-mail to the researcher) were received from all 10 universities in the study. The initial contact list included any librarian who collected for any subject 
taught in the film studies program, but it turned out that film collections are built primarily by one person at all of the libraries surveyed.

Online surveys were exported from Fluid Surveys to Excel for analysis. Paper surveys were entered into Fluid Surveys, randomly spot-checked to reduce data-entry errors, and exported to Excel. Open-ended questions were subjected to content analysis using grounded coding.

\section{Results}

The results of this research shed light on how students gain access to films required for their courses, how they would prefer to gain access, and the challenges faculty and librarians experience facilitating access. Unique results from students, faculty, and librarians are presented separately; then results of questions asked to all three groups are presented together.

\section{How do students access required films?}

As shown in table 1, the most common method of film access was watching the film during class; 59 percent of students always or usually did this. Only 12 percent said that they always or usually attended screenings outside of class time. However, only one of the three classes surveyed had screenings outside of class time $(n=14)$, which means that 43 percent of those students always or usually attended screenings outside of class. For the other two classes, whole films were not screened during regular class time, so students are referring to film clips shown in class.

\begin{tabular}{|l|c|c|c|}
\hline \multicolumn{4}{|c|}{ Tow Students Accessed Required Films } \\
\hline \multicolumn{1}{|c|}{ Method } & $\begin{array}{c}\text { \% Who said } \\
\text { Always or } \\
\text { Usually }\end{array}$ & $\begin{array}{c}\text { \% Who Said } \\
\text { Half the Time or } \\
\text { Occasionally }\end{array}$ & $\begin{array}{c}\text { \% Who Said } \\
\text { Never }\end{array}$ \\
\hline Watch in class & 59 & 16 & $\begin{array}{c}8 \\
\text { Not applicable 17 }\end{array}$ \\
\hline Free websites & 51 & 39 & 10 \\
\hline Download P2P & 42 & 12 & 46 \\
\hline Rent online & 14 & 17 & 69 \\
\hline Watch out of class with class & 12 & 4 & Not applicable 34 \\
\hline Buy DVD & 8 & 22 & 70 \\
\hline Reserve desk & $4 *$ & 27 & 69 \\
\hline Rent DVD & $2 *$ & $14 * *$ & 8 \\
\hline * Percentage of students who said Usually. Zero students said Always. \\
** Percentage of students who said Occasionally. Zero students said Half the time.
\end{tabular}

The second most common method was watching films on free websites. Just over half ( $51 \%$ ) of students reported that they always or usually did this, and only 10 percent had never done so. When asked to name the free websites, 29 students gave responses that included common video sites (YouTube, Vimeo) and subscription services legally available in Canada (Netflix). However, responses from 10 students also included subscription services not legally available in Canada (Hulu) and cloud storage "cyber- 
locker" sites (Megavideo, Putlocker, Sockshare). ${ }^{42}$ Four of the 10 students who named cyberlocker sites in this question later stated that they had never downloaded films through P2P applications. This points to a shift in digital piracy away from downloading and toward streaming; at least 8 percent of the students surveyed indicated that they used one and not the other. Given the popularity of free websites among students (only 10\% did not use them for the course), it may be surmised that more students used such sites but did not name them when asked.

Nearly half $(42 \%)$ said that they always or usually downloaded films via a common method of movie piracy - using peer-to-peer file-sharing software like BitTorrent and sites like Pirate Bay. However, 46 percent said that they never pirated films for the course through file-sharing.

The Reserve Desk was unpopular - 69 percent never used it. The largest reported uses of the Reserve Desk were half the time or occasional, by a total of 27 percent of students.

Renting and buying were the least popular methods. Only 2 percent reported usually renting DVDs, while 14 percent did it occasionally. More than four out of five $(84 \%)$ never rented DVDs. This may be due to preference, but it also likely reflects a decline in access to DVD rentals. DVD purchases were higher-30 percent reported buying DVDs for the course (with occasionally being the most common extent), while 70 percent reported never having done so.

Renting films online was marginally more popular than buying DVDs. Three out of ten $(31 \%)$ reported renting films online for the course (with occasionally being the most common), while 69 percent reported never having done so. An unfortunate limitation of this research is that the question about purchasing films online was accidentally omitted from the paper survey. However, results discussed in the next section suggest that the method is less preferred.

To discover how students would prefer to access films, they were given the same list of methods and asked to cross out any method they would never want to use, then rank the remaining methods in order of preference.

\begin{tabular}{|c|c|c|c|}
\hline \multicolumn{4}{|c|}{$\begin{array}{c}\text { TABLE } 2 \\
\text { How Students Would Prefer to Access Required Films }\end{array}$} \\
\hline Method & $\begin{array}{c}\text { \% Who } \\
\text { Ranked \#1 }\end{array}$ & $\begin{array}{c}\text { \% Who Ranked } \\
\# 1,2 \text {, or } 3\end{array}$ & $\begin{array}{c}\text { \% Who Ranked } \\
\text { Never }\end{array}$ \\
\hline Watch in class & 43 & 73 & 10 \\
\hline Free websites & 22 & 77 & 6 \\
\hline Download P2P & 22 & 43 & 35 \\
\hline Watch out of class with class & 20 & 43 & 29 \\
\hline Rent online & 4 & 12 & 68 \\
\hline Rent DVD & 2 & 8 & 74 \\
\hline Buy DVD & 2 & 8 & 65 \\
\hline Reserve desk & 0 & 28 & 32 \\
\hline
\end{tabular}

Table 2 shows the methods most often ranked among the top three. Watching the film during class was ranked first by the largest number of students (43\%). Free websites and P2P downloading were the next most popular, both ranked first by 22 percent of students. However, a substantially larger number of students (77\%) ranked free websites among their top three preferences than ranked P2P downloading among their top three preferences (43\%) (see figure 1). 


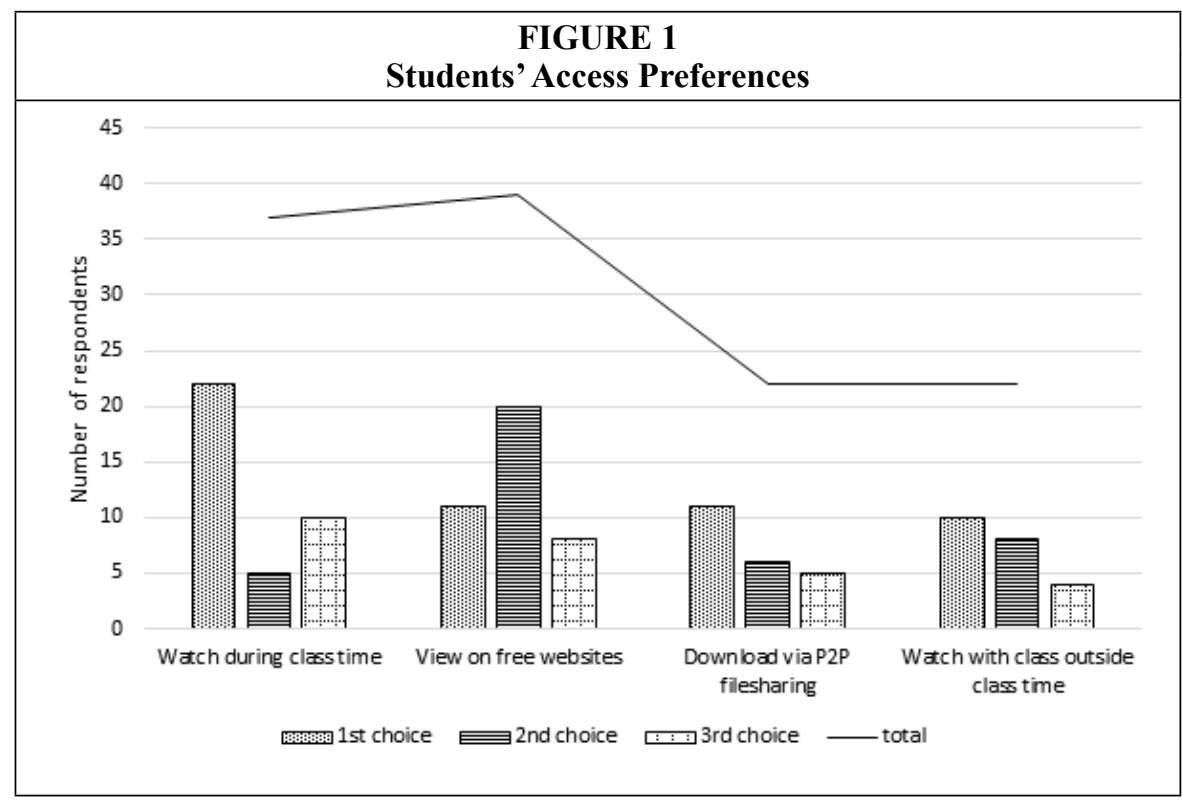

Zero students ranked the Reserve Desk as their top preference. Nearly three out of ten $(28 \%)$ ranked it in their top three, and it ranked just above the fee-based options.

Paying for access is not preferred. Nearly three-quarters (74\%) said they would never want to rent DVDs, 65 percent would never want to buy them, and 68 percent would never want to rent films online. That the majority are unwilling to rent online or buy DVDs suggests that a significant number would also be unwilling to buy streamed or downloadable films, an option that was accidentally omitted from the paper survey. In addition, no one listed buying online films as a preference in the "Other" space provided, which adds further weight to the supposition that it is a less preferred option.

When asked whether their ideal method of access involved a combination of approaches, 10 percent of students specified that they would like to watch the film in class and then have access to it online later, a combination of the two most preferred methods.

Students were asked, "When thinking about how to obtain access to films required for your courses, how important are the following factors to you?" Nine factors were listed with this scale: Extremely important, Very important, Moderately important, Slightly important, and Not at all important. Two blank spaces yielded no additional insights.

The items most often ranked "Extremely important" or "Very important" are:

- I want to obtain the film for free $=73 \%$

- I want to watch the film according to my own schedule $=69 \%$

- I want to watch the film more than once $=62 \%$

- I want to store the film on my own device for future use during the course $=57 \%$

The free factor appears to be inversely proportional to another factor: "I want to obtain the film legally" (see figure 2). Nearly three-quarters (73\%) of students considered free access to be extremely or very important, while only 6 percent deemed it not at all important. The response to the legal factor was skewed in the other direction, though with slightly more balance. Three out of ten $(30 \%)$ of respondents deemed legal access to be extremely or very important, while 42 percent considered it not at all important.

The factors related to multiple viewings, storage, and ownership (see figure 3 ) raise questions about their interpretation by students. 


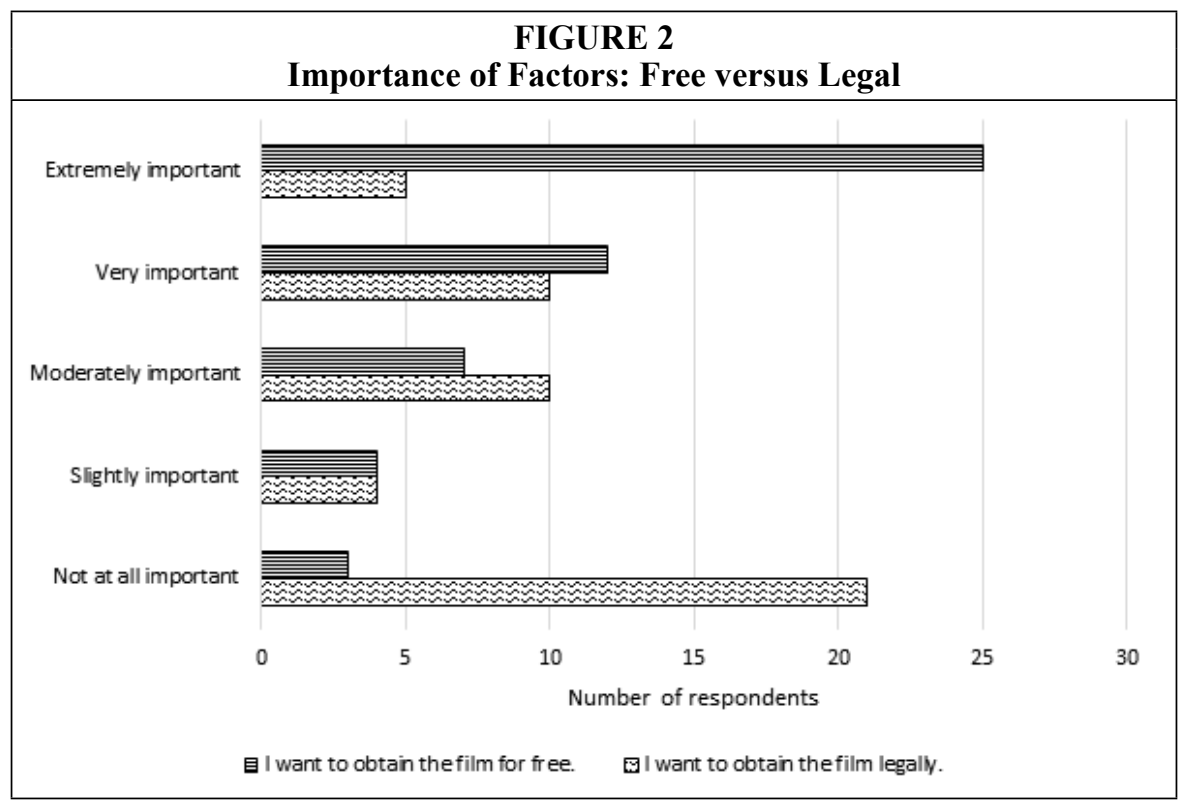

Just under two-thirds (65\%) said it was not at all important to "...own the movies I watch for courses, just like I own my textbooks." However, 57 percent said that it was extremely or very important to "...store the film on my own device for future use during the course." It may have been the reference to textbooks that led to the apparent lack of importance of ownership; new trends in textbook access (rental, piracy, and open educational resources) perhaps mean that fewer students now own textbooks. This

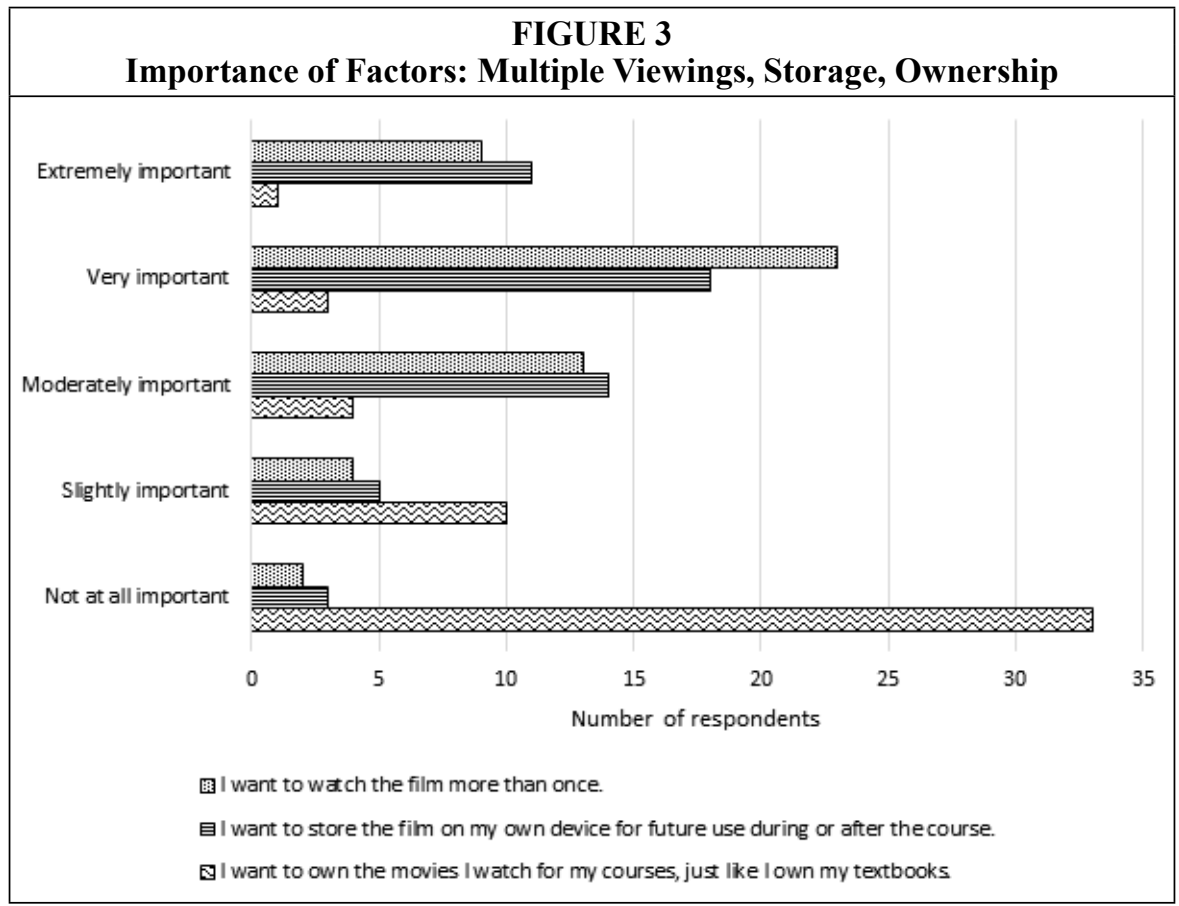


discrepancy may also suggest a different interpretation of "ownership" (that is, you "own" it when you pay for it but not when you pirate it). A comment from a student later in the survey supports this possibility: "I think any real film student will, especially in foreign film, forgo all 'buying' and download or stream. This is a generation of shifting ideas of what 'copyright' and 'piracy' mean."

One factor was unique to DVDs: "I want to watch the DVD to see the special features and packaging." This factor was not at all important to 67 percent of respondents. Only 4 percent considered it to be extremely or very important.

Students were asked, "Which format do you prefer?" Nearly half indicated this order of preference: Download, streaming, DVD (see figure 4). Two-thirds (67\%) listed an online format as their top preference, while 27 percent preferred DVDs most.

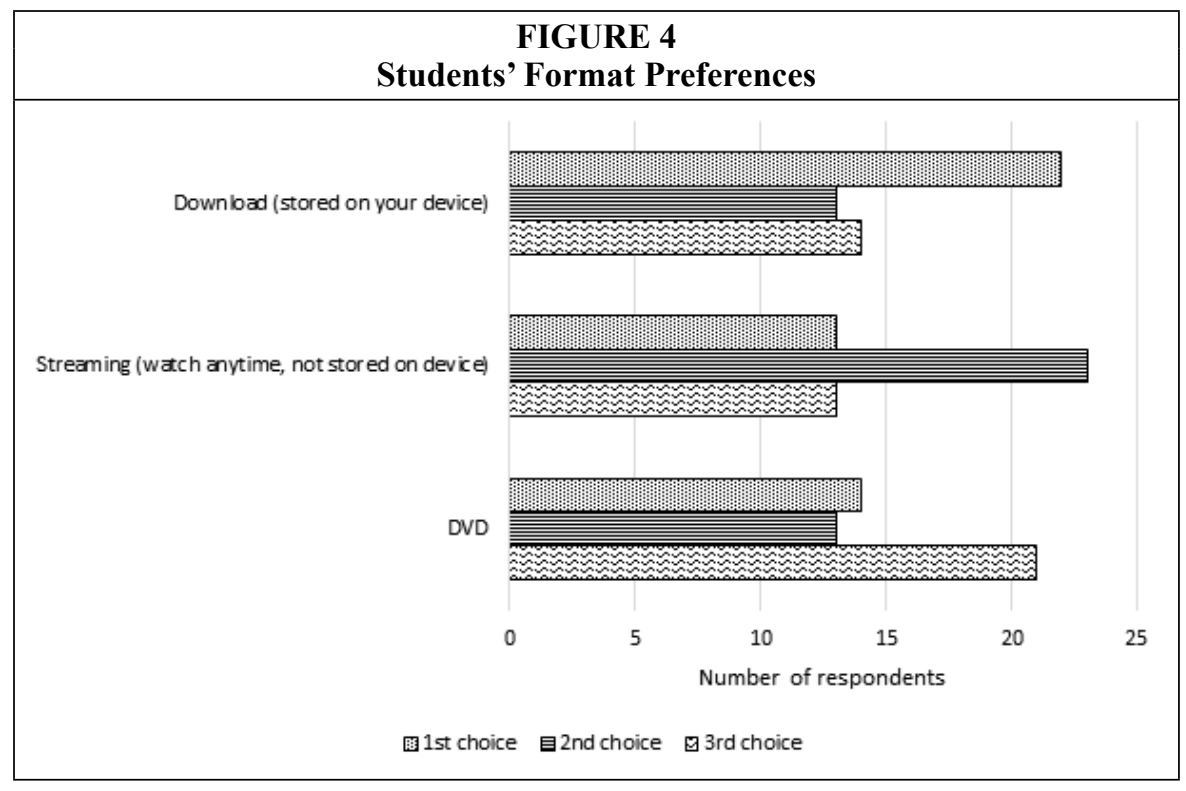

Students were asked, "Is it your responsibility to obtain the films required for your courses?" More than three-quarters (78\%) answered yes. Twenty students added comments, half of which focused on access issues, such as: "Yes it is my responsibility to obtain films required for the courses, but professors, the bookstore and library need to make films easier to obtain especially for distance courses."

\section{How do professors facilitate access?}

Professors facilitate access to films primarily by screening some or all films during class time (81\%) and placing library copies on Reserve (79\%). Just under half place personal copies on Reserve. Half of respondents report that they tell students where to find films on free websites or via subscription services. One-quarter (33\%) lend personal copies directly to students, and 27 percent screen films outside of class time.

Professors believe that students also acquire films by illegally downloading (68\%), renting (62\%), and buying (48\%), in that order. They believe that some students also borrow DVDs from friends or the public library.

A representative comment reveals a "don't ask, don't tell" policy:

I have made it my policy not to ask HOW the students are viewing the films, 
since I know most are doing so illegally. I do not encourage this, and I ensure legal access is available, but many students are so used to illegally downloading media that their first instinct is to view the films that way.

More than nine out of ten (92\%) reported that some or all of their films are available in the campus library, and 90 percent reported that they always or sometimes ask the library to purchase films. The most common reason for not always asking was positive: "The library already has the films and/or regularly adds to the film collection, so I do not need to make a special request to have the films bought by the library." The second most common reason was that the films were held in a department or faculty film library. The third reason is disappointing: "The library does not have a budget for purchasing films."

Other reasons added by respondents included that films were available through a free digital archive, professors bought the films themselves for class screening, and films are not available on DVD. One comment perhaps points to a misunderstanding about the mandate of a university library: "The films are not 'academic' per se, and so it never occurred to me to ask the university library to purchase them."

Those who have taught film studies courses entirely through distance education $(8 \%)$ have had access to fewer titles. In one case, the course had to be restricted to titles on iTunes. In another, an educational broadcaster facilitated screening but "severely limited my control over title selection." However, one distance educator reported a positive experience:

The films are being shown in a password protected site, on a previously established legal precedent that an online classroom is still a classroom, and so you can show a film there as you can in a regular classroom.

\section{How do librarians facilitate access?}

Librarians facilitate access by responding to faculty requests for films in advance of the course $(100 \%)$, "rush" ordering films after the term has started $(80 \%)$, and regularly adding to the collection when funds allow (20\%). No one reported adding records to their library catalogue for copyright-cleared films available for free online.

Six libraries have a specific budget for films, while three buy films with the budget related to the subject or language of the film (three libraries with dedicated budgets do this as well). Budgets range from $\$ 500$ to $\$ 150,000 \mathrm{CDN}$; nearly half are around $\$ 10,000$. Only one library has a collections policy specifically for film or audiovisual materials.

All libraries circulate DVDs, and nearly all put films on Reserve by request. DVD circulation has declined at three libraries, but it remains steady at one. Three libraries subscribe to streaming video packages used in Film Studies courses on their campuses, including Films on Demand, Kanopy, NFB Campus, and Theatre in Video.

Half of the librarians surveyed believe that students on their campuses are committing digital piracy. Some libraries report that they are facilitating discussions about copyright issues on campus. One library hosts sessions for faculty, while another librarian has had informal conversations with film studies faculty and provides information on the library website. When asked to describe discussions about film copyright taking place on campus, one respondent was very direct:

If a film is out of print or otherwise not legally available in Canada, and if the film might otherwise be available online by nefarious networking means, I will inform patrons of the fact, and advise them that I would never in good conscience 
advise them to avail themselves of those means. You catch my drift? If they're looking for the film it is because they need it for academic purposes, and our protectionist IP regime is sometimes an unfortunate hindrance.

\section{Who is file-sharing?}

To gauge awareness of film piracy, all three groups were asked: “Do you know how to illegally download films through peer-to-peer file-sharing applications or gateway sites (such as BitTorrent, Pirate Bay)?" and "Have you ever illegally downloaded films through peer-to-peer file-sharing applications or gateway sites (such as BitTorrent, Pirate Bay)?"

As shown in figure 5, students are the most knowledgeable (71\%) and the most likely to have done it $(60 \%)$. More than half of librarians $(60 \%)$ and one-third of faculty reported knowing how, though only 17 percent of librarians and 14 percent of faculty had done it.

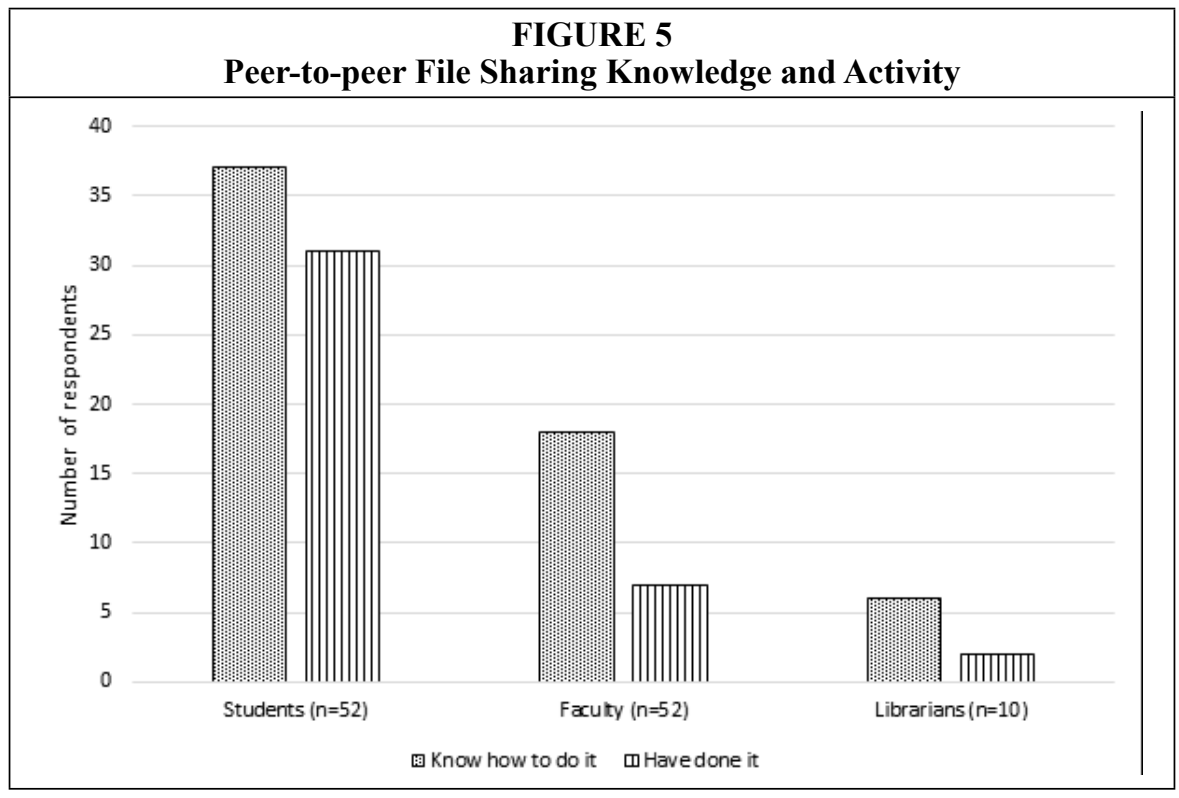

Additionally, students were asked, "Are you aware that downloading films through peer-to-peer file-sharing applications, gateway sites, or other free online methods is illegal if the films are covered by copyright?" More than nine out of ten (92\%) students said yes.

\section{How can access be improved?}

All three groups were asked the open-ended question, "How could students' access be improved?" and also given a space for comments at the end of the survey. Comments from 35 students, 36 faculty, and 10 librarians yielded 151 narrative statements that were content coded and grouped thematically, resulting in five suggestions and five challenges.

\section{Suggestions}

1. Increase online viewing options, suggested by 43 percent of students, 33 percent of faculty, and 80 percent of librarians. 
Students called for password-protected online access to the films through the library, the course management system, or the bookstore. One student put the suggestion into the context of existing library services: "an online resource provided by the library, just like the web versions of books and journals." Half of faculty respondents suggested that the library should be the provider, either by streaming DVDs or buying access to video on demand.

It is worth noting that 15 percent of students emphasized legality and the downsides of piracy when calling for better online options. One referred to "the hassle of having to go through 50 sites" to find a film, and another highlighted the risk of exposing one's computer to viruses and malware.

2. Provide larger library budgets ( $28 \%$ of faculty, $70 \%$ of librarians)

Many respondents qualified their comments with reference to one of the challenges discussed below: price.

3. Screen films in class ( $17 \%$ of students, $17 \%$ of faculty)

One professor suggests "introducing scheduling that allows screening time in addition to regular class hours so the films can be watched collectively." Poor class attendance is a related issue noted by 12 percent of faculty, as is the issue of screen time reducing the amount of time available to teach.

4. Improve Reserve service ( $17 \%$ of students, $17 \%$ of faculty)

The most common suggestions were to add more DVD copies and offer Reserve films online. Three students and one professor called for changes to loan periods: two hours is too short and overnight is too long.

But Reserve is also contentious. Several faculty stated that Reserve DVDs are insufficient. Two students reported not having DVD drives on their laptops (an increasingly common setup). For titles unavailable to rent or buy digitally, one student without a disc drive saw the "only option being to download/stream illegally." Librarians did not specifically mention Reserve; they focused on streaming options that typically do not need to be "Reserved."

5. Improve screening space on campus ( $8 \%$ of faculty, $20 \%$ of librarians)

Two professors noted the need for a screening room in the library, and one wrote, "Designated, attractive, multiperson (and thus social) screening spaces in libraries might help encourage students to view legal copies of DVDs." Two professors also noted that their classrooms were less-than-ideal screening spaces. Two librarians suggested the need for dedicated screening space elsewhere on campus. Notably, zero students suggested better screening spaces. Rather, two students expressed dissatisfaction with viewing films in the library (for instance, "I prefer not to watch films in public places like the library).

\section{Challenges}

1. Copyright and availability ( $22 \%$ of faculty, $70 \%$ of librarians)

While copyright and availability are separate issues, they are inextricably linked. Most references to copyright were related to specific issues of availability (age, region, language, format of DVDs).

Faculty and librarians reported that, in addition to being unavailable online, foreign films are often unavailable on DVD in North American region format with subtitles. Others are out of print even on VHS due to having "fallen into a rights limbo," or not available online because they are too obscure to be digitized profitably. The mainstream titles online are not typically licensed to institutions, so access could be improved if "Netflix or iTunes was available to institutions," as one librarian wrote. Even when films are available, one professor observed that screening them can be a challenge due to "stringent copyright rules about classroom presentation imposed by some distributors." 
2. Price (6\% of faculty, $30 \%$ of librarians)

Some noted that price was beyond the library's control: limited budgets would stretch further "if film companies would reduce the price of purchasing films for use on campus," one professor wrote.

3. Liaison ( $3 \%$ of faculty, $30 \%$ of librarians)

Librarians identified collaboration with faculty as a possible solution to access issues (for instance, "more time to perform liaison work"). One professor perceived a deficit in library services: "Have librarians able to cope with copyright issues."

4. Cataloguing ( $10 \%$ of librarians)

One respondent wrote, "I am uncertain if catalogue records for copyright cleared web available (YouTube, etc.) films would improve access." On the one hand, catalogue records may be a waste of time if students are turning exclusively to the open web. However, as online is the preferred format, it might be useful to have free titles catalogued alongside purchased titles.

5. Pedagogical demands ( $8 \%$ of faculty)

Access affects pedagogy in a number of ways. Some films cannot be included on the course syllabus due to price, and other titles are omitted if not online, as one faculty member explains:

I have found that students are more likely to download/stream films in their own homes (both legally and illegally) than to seek out DVD copies, so given a choice between two pedagogically similar films, I tend to put the one legally available online on the syllabus. Free sites such as YouTube are preferable....

Despite the ease of access, YouTube and similar sites also raise pedagogical issues. One professor wrote, "I am concerned that they are watching edited, segmented, or films with commercials... or censored... [or] watching them on their phones... [I am] concerned about the size and incorrect aspect ratio."

\section{Limitations of This Research}

This study was limited to how film studies students obtained films required for their classes, and so is not necessarily applicable to how they obtain films for other purposes. The survey was limited to Canadian participants. Faculty and librarians from only 10 institutions were surveyed, and students from only one institution were surveyed. It is difficult to generalize these findings to the larger population. No relationships were discovered between demographic variables and how respondents accessed or facilitated access to films, and this is likely due to the small sample size. As noted earlier, a question about buying films online was accidentally omitted from the student surveys, though answers to other questions allow one to make inferences about the omitted option. The wording of questions related to piracy was skewed toward P2P downloading rather than streaming, which is an increasingly popular means of acquiring copyrighted material for free. Indeed, in a news item reporting that the University of Calgary has restricted access to BitTorrent sites as of November 1, 2016, students doubted that the move would slow digital piracy because BitTorrent is considered "old school" by some students, one of whom explained: "When it comes to movies and stuff you're pretty much streaming it." ${ }^{\prime 3}$

\section{Recommendations and Conclusion}

This project began with the expectation that few students were using the Library's Reserve Desk to obtain films, that more students were engaging in digital piracy than using Reserve, and that faculty and librarians were encountering challenges in trying 
to provide effective and legal access to films. All three assertions were found to be true. The largest reported use of the Reserve Desk was occasional by 22 percent of students, while 42 percent said that they always or usually downloaded films using P2P filesharing applications. Faculty and librarians reported a host of confounding challenges.

There is no single solution to these challenges, but treating users who commit piracy as "sources of legitimate justifications," is a good place to start. ${ }^{44}$ More than nine out of ten (92\%) students know that downloading copyrighted films through P2P or other free online methods is illegal. Yet 60 percent have done it anyway, reportedly turning to illegal sources because legal channels were inconvenient, expensive, or unavailable. Nearly three-quarters (73\%) of students report that obtaining the film for free is extremely or very important to them. Only 30 percent view legal access the same way. Most students (78\%) see it as their responsibility to obtain access to required films. Strover and Moner find that students want a legal alternative. ${ }^{45}$ Tryon and Dawson observe that convenience matters to students. ${ }^{46}$ Librarians and educators need to do more to support students, recognizing that the system - not the student-is dysfunctional.

The literature review suggests that online streaming has many advantages; the results of this research confirm that the majority of respondents would prefer increased online options. More than three-quarters $(77 \%)$ of students ranked watching films on free websites among their top three preferred methods of acquiring access to films. Regarding format, 67 percent listed an online format as their top preference. The most common suggestion to improve access was to increase online viewing options, according to 43 percent of students, 33 percent of faculty, and 80 percent of librarians. Together, this evidence indicates that libraries should increase streaming offerings. Yet the literature review and survey results demonstrate that libraries are limited primarily by the availability of appropriate streaming content, and secondarily by price. Streaming services that offer institutional licenses, such as Kanopy, do not offer the variety of feature films required by film studies programs. Consumer-oriented streaming services (such as Netflix, iTunes, Google Play, FilmStruck) that provide feature films do not offer licenses to libraries.

As noted in the literature review and by faculty and librarian respondents, DVDs offer tangibility, viewing quality, and relative legal simplicity. This suggests that libraries should continue to purchase DVDs for longer-term preservation right now; it is of course hard to predict what media will look like even 5 or 10 years from now. But should academic libraries continue to put DVDs on Reserve for film studies courses? Nearly eight out of ten (79\%) faculty report placing DVDs on reserve for their students, yet more than two-thirds of students did not use the Reserve Desk; those who did only used it sporadically. Zero students ranked it as their top preference; 28 percent ranked it among their top three. In terms of format, only 27 percent most preferred DVDs. Given the strong support for online options from respondents, libraries should seek to offer titles through legal streaming services when possible. In addition, libraries should convert syllabus-required DVDs to streaming files for use within password-protected courseware, as reported by King, Kong, and Vallier, and noted by faculty and student respondents. When neither option is possible, libraries should continue to make DVDs available on Reserve, while monitoring developments in access options.

Digitizing DVDs for online classrooms is not a universal solution, even for curricular needs. Licensing and copyright law must be considered on a case-by-case basis, according to the University of Michigan Libraries' “Options for Using Film in Courses." ${ }^{47}$ Institutions will have differing abilities to support the related technical and legal issues. Further, this solution does not support broader curricular goals: in other words, films may be streamed only to students enrolled in a designated class and not those who seek to view a film as a secondary source for research in a different 
course. Such students would have to borrow the library's DVD; instead, they may turn to piracy for an online option.

Watching the film during class was ranked as the most preferred method by nearly half of students (43\%). The majority of professors $(81 \%)$ report that they already screen some or all films during class time. However, professors may want to consider seeking changes to the class schedules used for film studies to include a "lab" or "studio" component (as applied arts and science courses typically do), and use the extra time for collective viewing at the proper size and aspect ratio. Nearly seven out of ten $(69 \%)$ students say that watching the film according to their own schedule is extremely or very important; an official class devoted to screening may be seen as such because students commit to the time when they register for the class. Class screening would not obviate the need for other access, however. In order to study and write about films, students must be able to view the film more than once and control the viewings (pause, fast forward, rewind).

The need for better screening space on campus was raised by faculty and librarians, though not by students. This is a possible avenue for future research, particularly to confirm students' interest or lack thereof in a "social" screening space, as suggested by one professor. Libraries already equipped with group screening space could examine usage and gather student opinions. For libraries without an existing group screening space, a pilot project could be undertaken using library meeting rooms and working with professors and students to create an ad hoc booking system for small groups.

Of the feature film industry, Handman writes that "librarians and educators are almost completely unlikely to have any say in the direction or practices of this industry." ${ }^{48}$ Nevertheless, stating our case may be our only recourse. Iordanova suggests that faculty and librarians should lobby filmmakers and distributors for better access and prices, particularly for educational viewing. ${ }^{49}$ There is also a need to lobby for changes to copyright law to allow libraries to consistently convert DVDs to streaming format for use both within and outside of online classrooms. For Canadian content at least, law professor Michael Geist suggests that "obscurity remains a far bigger threat than piracy." ${ }^{50}$ Perhaps there is a need for an Open Access movement for feature films, though such a movement would be highly unlikely given that feature film, as Handman writes, "exists in a separate market universe... because of its size, corporate complexity, revenues, and target audiences." ${ }^{51}$

Content creators want their work to be remunerated, but they also presumably want their work to be remembered. As memory institutions, libraries are the perfect place to preserve such a legacy. "We can't expect [Netflix] to feel some sense of responsibility towards cinema, despite the large role they've played in putting our most reliable source of old movies [video stores] out of business," writes Jason Bailey. ${ }^{52}$ Indeed, libraries and video stores united during the course of this research. One professor had reportedly dispensed with library services, writing in the survey that students' access to films could be improved "through Video Difference when I send the manager my course outline." However, this Halifax, Nova Scotia, video store closed permanently during the preparation of this article, and Dalhousie University Libraries and Halifax Public Libraries bought part of the store's collection. ${ }^{53}$ It is clear from this twist of fate that the open market is unreliable and that libraries must reassert and increase our role in film access and preservation for the academy and beyond. 


\section{APPENDIX A. Student Survey Questions}

1. How old are you?

18 or younger / 19-24 / 25-34 / 35-44 / 45-54 / 55-64 / 65-74 / 75 or older

2. How do you identify your gender? [blank]

3. For how many years have you been taking university courses?

This is my first year / 2 years / 3 years / 4 years / 5 years / 6 or more years

4. Approximately how many courses have you taken that required you to watch feature films?

This is the first / 2-3 courses/ 4-5 / 6-7 / 8-9 / 10 or more

5. How did you typically obtain access to films required for this course? [Options were Always, Usually, Half the time, Occasionally, Never, Not applicable.]

- I viewed films when the professor showed them during class time.

- I viewed films when the professor showed them outside of class time.

- I viewed films obtained by a classmate with a group from the class.

- I borrowed the professor's personal copies of films directly from him or her.

- I borrowed films from the Reserve Desk in the campus library.

- I borrowed films from a film library maintained by the department giving the course.

- I viewed films on free websites (examples: Archive.org, YouTube, Vimeo).

If yes, name some of the sites you used:

- I downloaded free films through peer-to-peer file-sharing applications or gateway sites (examples: BitTorrent, Pirate Bay).

- I rented films in DVD format from video stores or services (examples: Redbox, Zip.ca).

- I rented films in streaming format from online stores (example: iTunes).

- I bought films in DVD format from the campus bookstore.

- I bought films in DVD format from other (off-campus) stores or online stores.

6. Considering the same list of methods from the previous question, use the list below to label the methods as follows:

a. Mark an $\mathrm{X}$ next to any method you would never want to use. $X$ as many as you wish.

b. Rank the remaining methods in the order you prefer them, where $1=$ most preferred, 2 = second most preferred, and so on. Rank as many as you like.

$\square \quad$ View films when the professor shows them during class time.

$\square \quad$ View films when the professor shows them outside of class time.

$\square \quad$ View films obtained by a classmate with a group from the class.

$\square \quad$ Borrow the professor's personal copies of films directly from him or her.

$\square$ Borrow films from the Reserve Desk in the campus library.

$\square \quad$ Borrow films from a film library maintained by the department giving the course.

$\square \quad$ View films on free websites (examples: Archive.org, YouTube, Vimeo).

$\square \quad$ Download free films through peer-to-peer file-sharing applications or gateway sites (examples: BitTorrent, Pirate Bay).

$\square \quad$ Rent films in DVD format from video stores or services (examples: Redbox, Zip.ca).

$\square \quad$ Rent films in streaming format from online stores (example: iTunes). 
$\square \quad$ Buy films in DVD format from the campus bookstore.

$\square \quad$ Buy films in DVD format from other (off-campus) stores or online stores.

Other: [blank]

7. If your ideal method involves a combination of the above, please comment:

8. When thinking about how to obtain access to films required for your courses, how important are the following factors to you? [Options were Extremely important, Very important, Moderately important, Slightly important, and Not at all important.]

- I want to watch the film more than once.

- I want to store the film on my own computer for future use during the course.

- I want to watch the film alone or with friends, not with the whole class.

- I want to watch the film according to my own schedule.

- I want to watch the DVD to see the special features and packaging.

- I want to obtain the film for free.

- I want to obtain the film legally.

- I want to watch the film with a group of classmates.

- I want to own the movies I watch for courses, just like I own my textbooks.

- Other factors: [2 blank lines]

9. Is it your responsibility to obtain the films required for your courses?

- Yes, it is my responsibility

- No, it is not my responsibility

- If you have further thoughts on this, please explain:

10. Which format do you prefer? Please rank the options below from 1 to 3 or 1 to 4 , where 1 = most preferred.

Download (can be stored on your device)

DVD

Streaming video (can be watched online anytime, but cannot be stored on your device) Other: [blank]

[Options for questions 11-14 were $\square$ Yes / $\square$ No / $\square$ Prefer not to say.]

11. Do you know how to download films through peer-to-peer file-sharing applications?

12. Have you ever downloaded films through peer-to-peer file-sharing applications?

13. Are you aware that downloading films through peer-to-peer file-sharing applications, gateway sites, or other free online methods is illegal if the films are covered by copyright?

14. Are you satisfied with the access you currently have to films required for your courses?

15. How could your access be improved?

16. Other comments (optional) 


\section{APPENDIX B. Faculty Survey Questions}

1. For how many years have you been teaching university courses for which students must watch films?

1-5 years / 6-10 / 11-15 / 16-20 / 21-25 / 26-30 / 31-35 / 36 or more years

2. How old are you?

19-24 /25-34 / 35-44 / 45-54 / 55-64 / 65-74 / 75 or older

3. How do you identify your gender? [blank]

4. In what ways do you typically facilitate students' access to the films required for your courses? Please check all that apply.

- I screen some or all films during class time.

- I screen some or all films outside of regular class time.

- I lend my personal copies directly to students.

- I place my personal copies of some or all films on Reserve in the campus library.

- I lace library-owned copies of some or all films on Reserve in the campus library.

- My department or faculty maintains a film library (not overseen by the campus library), and I encourage my students to use it.

- I tell students where to find films on free websites (examples: Archive.org, YouTube, Vimeo).

- I tell students whether films are available through a subscription service like Netflix.

- The campus bookstore sells copies of the films required for my courses alongside the textbooks for my courses.

- Other: [blank]

5. Based on your interactions with students, in what other ways do you think they obtain the films required for your courses (in addition to the ways you facilitate)? Please check all that apply.

- Students rent films in DVD format.

- Students rent films online in streaming or download format.

- Students buy films in DVD format (not from the campus bookstore).

- Students buy films online in streaming or download format.

- Students illegally download films through peer-to-peer file-sharing applications or gateway sites (example: BitTorrent, Pirate Bay).

- Other: [blank]

6. Thinking of a typical film course you taught recently, and based on your interactions with students, estimate to the best of your knowledge what percentage of your students likely obtained access to required films in the following ways:

[Options were: $75 \%-100 \%$ used this method / 50\%-74\% used this method / $25 \%-49 \%$ used this method / fewer than 25\% used this method / Not applicable / Don't know]

- Students viewed films at screenings I organized.

- Students borrowed films directly from me.

- Students borrowed films from the Reserve desk in the campus library.

- Students borrowed films from a library maintained by my department or faculty.

- Students viewed films on free websites (examples: Archive.org, YouTube, Vimeo).

- Students viewed films through a subscription service like Netflix.

- Students rented films in DVD, streaming, or download format.

- Students bought films in DVD, streaming, or download format.

- Students illegally downloaded free films through peer-to-peer file-sharing applications or gateway sites (examples: BitTorrent, Pirate Bay). 
The next two questions are included to help determine your level of understanding of activities that your students may be pursuing.

7. Do you know how to illegally download films through peer-to-peer file-sharing applications or gateway sites (examples: BitTorrent, Pirate Bay)? Yes / No / Prefer not to say

8. Have you ever illegally downloaded films through peer-to-peer file-sharing applications or gateway sites (examples: BitTorrent, Pirate Bay)? Yes / No / Prefer not to say

9. Are the films required for your courses available in your campus library collection? All are in the library / Some are in the library / None are in the library / I don't know

10. Do you ask the campus library to purchase the films required for your courses? Always / Sometimes / Never

11. If you said Sometimes or Never, please indicate why you do not always ask the campus library to purchase films required for your courses. Choose all that apply.

- The library already has the films and/or regularly adds to the film collection, so I do not need to make a special request to have the films bought by the library.

- The films are already held in my departmental or faculty film library (which is not overseen by the campus library).

- The films are like textbooks, so it is the students' responsibility to acquire them.

- Many of the students prefer to find copies they can keep, so I think it would be a waste of money for the library to buy the films.

- The library does not have a budget for purchasing films.

- I do not know who to contact in the library about purchasing films.

- Other: [blank]

12. Since you started teaching Film Studies, have you changed your approach to ensuring that students have access to films? [Options were: Have always done and continue to do, Have started doing, Have stopped doing, or Have never done.]

- Screen some or all films during class time.

- Screen some or all films outside of regular class time.

- Lend my personal copies directly to students.

- $\quad$ Place my personal copies on Reserve in the campus library.

- Place library-owned copies on Reserve in the campus library.

- Encourage students to borrow films from my departmental or faculty library.

- Tell students where to find films on free websites or via subscription services.

- Order films for students to buy through the campus bookstore.

13. Have you ever taught a Film Studies course entirely through distance education (that is, with no face-to-face contact)? Yes / No

If applicable, please comment on any additional challenges you faced when facilitating access to films for distance education courses.

14. Overall, are you satisfied with the access your students currently have to films required for your courses? Yes / Somewhat / No

15. How could students' access be improved?

16. Other comments (if any). 


\section{APPENDIX C. Librarian Survey Questions}

1. For how many years have you been collecting films that are used in the Film Studies program?

1-5 / 6-10 / 11-15 / 16-20 / 21-25 / 26-30 /31-35 / 36 or more years

2. How old are you?

19-24 /25-34 / 35-44 / 45-54 / 55-64 / 65-74 / 75 or older

3. How do you identify your gender? [blank]

4. Does your library have a specific budget or fund for purchasing films?

- Yes, most films are bought from one specific budget or fund.

- No, films are bought using the budget related to the subject or language of the film, or the department that will be using it.

- Other: [blank]

5. If your library has a specific fund for purchasing films, please state the amount of the fund for the last fiscal year.

6. Does your library have a collections policy specifically for films and/or audiovisual materials?

- Yes, my library has a collections policy specifically for films and/or audiovisual materials.

- My library's film policy is part of a single larger library collections policy.

- Film is a format that is included in many different subject-based collections policies at my library.

- My library does not have a collections policy or policies for any format or subject.

- I don't know.

- Other: [blank]

7. Does your library put films on Reserve for specific classes when they are required viewing for a course?

- Yes, my library automatically puts films on Reserve for all Film Studies courses.

- Yes, my library puts films on Reserve for Film Studies courses, but only at the professor's request.

- No.

- I don't know.

8. Does your library allow films on DVD to circulate outside the building? Yes / No

9. Does your library subscribe to streaming video packages that include films used in Film Studies courses? Yes / No

10. If yes, please name the streaming video packages you offer that include films used in Film Studies courses.

11. How do you ensure that students have access to the films required for Film Studies courses? Please check all that apply.

- Instructors contact me in advance of the course and request that I purchase the films they will require students to watch.

- I regularly add to our collection of films, so the films that instructors want are often already in the collection. 
- I "rush order" films when I discover they are required (as a result of students or faculty asking for them after the course has begun).

- I request course outlines or lists of required films from instructors prior to the start of each term and buy missing titles.

- When I discover that copyright-cleared films are available for free online, I add a record to the catalogue for the whole site (such as Archive.org).

- When I discover that copyright-cleared films are available for free online, I add records to the catalogue for individual film titles.

- Other: [blank]

12. Considering the past 5 years, do you think there has been a decline in the circulation and/or use of films at your library?

- Yes, I have seen the circulation figures and there has been a decline.

- I suspect there has been a decline, but I have not seen the circulation figures.

- I do not think there has been a decline, but I have not seen the circulation figures.

- No, I have seen the circulation figures, and there has not been a decline.

- I don't know.

- Other: [blank]

13. Do you think that students at your institution illegally download films required for their courses through peer-to-peer file-sharing applications or gateway sites (examples: BitTorrent, Pirate Bay)? Yes / No / I don't know

14. Are there discussions in your library or on your campus about illegal downloading of films or other media? Yes / No / I don't know

15. If there are discussions in your library or on your campus, please describe:

The next two questions are included to help determine your level of understanding of activities that students at your institution may be pursuing.

16. Do you know how to illegally download films through peer-to-peer file-sharing applications or gateway sites (examples: BitTorrent, Pirate Bay)? Yes / No / Prefer not to say

17. Have you ever illegally downloaded films through peer-to-peer file-sharing applications or gateway sites (examples: BitTorrent, Pirate Bay)? Yes / No / Prefer not to say

18. Overall, are you satisfied with the access that students at your institution currently have to films required for Film Studies courses? Yes / Somewhat / No

19. How could students' access be improved?

20. Other comments (if any).

\section{Notes}

1. The Pew Research Center reports that "For some demographic groups-such as young adults, college graduates...-internet usage is near ubiquitous." Pew Research Center, Internet/ Broadband Fact Sheet (Jan. 12, 2017), available online at www.pewinternet.org/fact-sheet/internetbroadband/ [accessed 24 January 2017].

2. In January 2015, a Canadian law made it mandatory for Internet Service Providers, including 
universities, to forward copyright notices to alleged infringers. The notices come from companies such as Canadian Intellectual Property Rights Enforcement (CANIPRE). In 2015, CANIPRE sent 6 million notices, of which 300,000 went to universities, indicating that digital piracy is occurring on Canadian campuses. Michael Robinson, "Student Downloaders Beware," Maclean's 129, no. 44 (Nov. 7, 2016): 56-57.

3. A search conducted in January 2017 in the database Academic Search Complete using a broad search strategy, that is, piracy AND (digital OR internet OR online) and limited to publications since 2000, yielded 2,943 articles, 510 of which were categorized as being from scholarly or peer-reviewed journals. A search conducted in January 2017 in Google Scholar using the same broad strategy (but limited only to article titles) yielded 979 academic articles published since 2000. What is believed to be the first systematic review of the literature on the attitudes and behaviours of illegal downloaders evaluated more than 400 reports and papers chosen "from the thousands published": Peter Williams, David Nicholas, and Ian Rowlands, "The Attitudes and Behaviours of Illegal Downloaders," Aslib Proceedings: New Information Perspectives 62, no. 3 (2010): 283.

4. Benjamin Malczewski, "Film Format Pandemonium," Library Journal 135, no. 19 (2010): 26.

5. Gary Handman, "License to Look: Evolving Models for Library Video Acquisition and Access," Library Trends 58, no. 3 (2010): 326.

6. Rachel King, "House of Cards: The Academic Library Media Center in the Era of Streaming Video," Serials Librarian 67, no. 3 (2014): 298.

7. Ibid., 293.

8. Ibid., 300 .

9. Ibid., 301.

10. John Vallier, "Twenty-first Century Academic Media Center: Killer App or Chindogu?" Library Trends 58, no. 3 (2010): 387.

11. Haili Kong, "Reflections on Teaching Chinese Language Films at American Colleges," ASIANetwork Exchange: A Journal for Asian Studies in the Liberal Arts 18, no. 2 (2016): 25.

12. Bryan James McGeary, "Accessibility, Collaboration, and Staffing: Revamping the Model for Academic Library Video Collections," Public Services Quarterly 11, no. 4 (2015): 307-18.

13. Ciara Healy, "Netflix in an Academic Library: A Personal Case Study," Library Trends 58, no. 3 (2010): 409.

14. Such behaviour was not reported during this research project. However, when preliminary results were presented at the Ontario Library Association conference in Toronto, Ontario, in February 2015, a conference attendee reported having observed this behaviour at an institution not included in the study.

15. William Cross, "More Than a House of Cards: Developing a Firm Foundation for Streaming Media and Consumer-Licensed Content in the Library," Journal of Copyright in Education and Librarianship 1, no. 1 (2016): 15.

16. Jane Johnson Otto, "University Faculty Describe Their Use of Moving Images in Teaching and Learning and Their Perceptions of the Library's Role in That Use," College \& Research Libraries 75, no. 2 (2014): 115-44.

17. Ibid., 130.

18. Ibid., 133.

19. Ibid., 128.

20. Ibid., 139.

21. Dina Iordanova, "Instant, Abundant, and Ubiquitous: Cinema Moves Online," Cineaste 39, no. 1 (2013): 50.

22. Ibid., 47.

23. Ibid., 48 .

24. Ibid., 49 .

25. Dean Hendrix, "Peer-to-Peer (P2P) Knowledge, Use, and Attitudes of Academic Librarians," portal: Libraries and the Academy 7, no. 2 (2007): 191-212.

26. Kate Gray, "Stealing From the Rich to Entertain the Poor?: A Survey of Literature on the Ethics of Digital Piracy," The Serials Librarian 63, no. 3/4 (2012): 294.

27. See footnote 3 for details.

28. Steven Caldwell Brown, "Approaches to Digital Piracy Research," Convergence 20, no. 2 (2014): 130.

29. Ibid., 132.

30. Brown cites George E. Higgins and Catherine Davis Marcum, Digital Piracy: An Integrated Theoretical Approach (Durham, N.C.: Carolina Academic Press, 2011); Robert Morris and George Higgins, "Neutralizing Potential and Self-reported Digital Piracy: A Multitheoretical Exploration Among College Undergraduates," Criminal Justice Review 34, no. 2 (2009): 173-95; and Ruud S. Jacobs et al., "Digital Movie Piracy: A Perspective on Downloading Behavior Through Social Cognitive Theory," Computers in Human Behavior 28, no. 3 (2012): 958-67. See also Ramon Lobato, 
Shadow Economies of Cinema: Mapping Informal Film Distribution, Cultural Histories of Cinema, (London: Palgrave Macmillan on Behalf of the British Film Institute, 2012) for discussion of the "Six Faces of Piracy."

31. Lee Edwards et al., "Framing the Consumer: Copyright Regulation and the Public," Convergence 19 , no. 1 (2013): 10.

32. Chuck Tryon and Max Dawson, "Streaming U: College Students and Connected Viewing," in Connected Viewing: Selling, Streaming, E Sharing Media in the Digital Era, eds. Jennifer Holt and Kevin Sanson (New York, N.Y.: Routledge, 2014), 223.

33. Ibid., 227.

34. Ibid., 223.

35. Sharon Strover and William Moner, “The Contours of On-demand Viewing," in Connected Viewing: Selling, Streaming, E Sharing Media in the Digital Era, eds. Jennifer Holt and Kevin Sanson (New York, N.Y.: Routledge, 2014), 247.

36. Ibid., 242.

37. Tryon and Dawson, "Streaming U," 228.

38. Strover and Moner, "The Contours of On-demand Viewing," 242.

39. Tryon and Dawson, "Streaming U," 229.

40. Strover and Moner, "The Contours of On-demand Viewing," 250.

41. At the time of this research, Memorial University of Newfoundland offered a Minor in Film Studies. In 2016, it was changed to a Certificate in Film Studies.

42. A cyberlocker is a form of cloud storage. It differs from peer-to-peer file-sharing in that cyberlocker sites host video files intended for streaming, not downloading.

43. Dave Dormer, "Access to BitTorrent Restricted at University of Calgary," CBC News Calgary (last modified Nov. 14, 2016), available online at www.cbc.ca/news/canada/calgary/bittorrentaccess-ban-university-calgary-1.3848796 [accessed 13 November 2016].

44. Edwards et al., "Framing the Consumer," 10.

45. Strover and Moner, "The Contours of On-demand Viewing," 247.

46. Tryon and Dawson, "Streaming U," 227.

47. Cara L. Slavens, "Options for Using Film in Courses," University of Michigan Library (last modified Apr. 4, 2017), available online at https://www.lib.umich.edu/askwith-media-library/ options-using-film-courses [accessed 18 May 2017].

48. Handman, "License to Look," 325.

49. Iordanova, "Instant, Abundant, and Ubiquitous," 48.

50. Michael Geist, "Government-Backed Study Finds Piracy Fight a Low Priority for Canadian Rights Holders" (Aug. 8, 2016), available online at www.michaelgeist.ca/2016/08/governmentbacked-study-finds-piracy-fight-a-low-priority-for-canadian-rights-holders/ [accessed 11 January 2017].

51. Handman, "License to Look," 325.

52. Jason Bailey, "The Case for FilmStruck (and Against Netflix)," Flavorwire.com (Nov. 1, 2016), para. 3, available online at http://flavorwire.com/591936/the-case-for-filmstruck-and-againstnetflix [accessed 10 April 2017].

53. Rachel Ward, "Video Difference Film Collection Being Bought by Halifax Public Libraries, Dalhousie," CBC News Nova Scotia (Aug. 16, 2016), available online at www.cbc.ca/news/canada/ nova-scotia/dalhousie-university-halifax-public-libraries-video-difference-1.3722688 [accessed 8 September 2016]. 